\title{
A Reformulation of business education curriculum for the development of career opportunities among undergraduates of South Nigerian Universities
}

\author{
Chika Madu Ile ${ }^{1}$, James Edomwonyi Edokpolor ${ }^{2 *}$ \\ ${ }^{1}$ Department of Technology and Vocational Education, Faculty of Education, \\ Nnamdi Azikiwe University, Awka, Anambra State, NIGERIA \\ ${ }^{2}$ Department of Social Science Education, Faculty of Arts and Education, \\ Benson Idahosa University, Benin City, Edo State, NIGERIA \\ *Corresponding author: jedokpolor@biu.edu.ng
}

Received: 21 February 2020; Accepted: 26 March 2020; Published: 01 April 2020

To cite this article (APA): Fadilla, P. F., Abdullah, S. M., \& Wu, M. (2020). Does conformity occur during students' decision making for their careers?. Asian Journal of Assessment in Teaching and Learning, 10(1), 1-9. https://doi.org/10.37134/ajatel.vol10.1.1.2020

To link to this article: https://doi.org/10.37134/ajatel.vol10.1.2.2020

\begin{abstract}
Concerning on the rates social burden among the graduates of business education in Nigeria has provided an opportunity for the authors to extant the study to examine the current state of business education curriculum and the reformulation of business education curriculum equips the undergraduates with skills to start a business and engaging towards lifelong learning. A cross-sectional survey design was applied to achieve the objectives of the study. The design of the research is a quantitative method. Structured questionnaires were given to a sample of 289 participants (43 lecturers and 246 students) which were randomly selected across three universities in Nigeria. The data obtained are analyzed by the Statistical Package for Social Sciences (SPSS) version 23.0 and the mean statistic is used to answer the research questions and standard deviations are used to assess the degree to which participants' scores are clustered around the mean. The results show that the business education curriculum is theoretical in nature, as such does not have the capability of preparing students to become entrepreneurs and lifelong learners. Hence, the data shows that most of the respondents vote for business education curriculum prepares student to work for the entrepreneurs with mean 3.49 for lecturers and 3.67 for students. Moreover, the result shows that a change in business education curriculum could help to equip students with skills to engage in becoming an entrepreneur. Therefore, the managers of business education should endeavor collaborations with major stakeholders to capable of integrating the $21^{\text {st }}$-century skills and apprenticeship models into the business education curriculum. It will help to equip undergraduates with the skills needed to pursue entrepreneurial and lifelong learning careers upon graduation.
\end{abstract}

Keywords: Business education, Career opportunities, Curriculum reform, Graduates' skills gap, Lecturers and students, Social problems

\section{INTRODUCTION}

Business education is a practical-oriented programme which aimed at equipping students' with the higher order skills needed to be capable of engaging in decent employment and lifelong learning activities immediately after graduation. It is one of the major areas of technology and vocational education in Nigeria that is central to the development of 21st century skills required by young individuals to function effectively in entrepreneurial and educational career endeavours after graduation. Titiloye and Muhammed (2016) reiterated that business education is a programme that prepares the mind, the brain, and the physical body of students toward positive contribution to national development. The overriding goals of business education as pointed out by Edokpolor and Egbri (2017) 
shall be to prepare the recipients for career advancement in office occupation; to equip the students with the skills for entrepreneurial venturing, and to expose the students to the knowledge about business. Based on these major goals, business education can be seen as a catalyst for securing core values of economic development (e.g., quality living, self-esteem, and freedom from social servanthood).

In spite of its potential role, as exemplified above, business education students still graduate without possessing the 21st century skills required to engage in entrepreneurial and lifelong learning activities. As a consequence, business education students who do not possess the 21 st century skills may probably become unemployed or underemployed and would not have the self-confidence and determination to further participate in lifelong learning activities immediately after graduation. The premature skills possessed by the business education students could be viewed as one of the key factor responsible for the increasing rates of unemployment and all manner of social ills.

In Nigeria, research have shown that the unemployment and underemployment rates are on the increase, with examples being: $25.5 \%$ of young individuals between the ages of 15 and 35 years old were unemployed in the third quarter of 2017 and increased to $30.50 \%$ in the second quarter of 2018, and $52.6 \%$ of young individuals between the ages of 15 and 34 years old were unemployed in the third quarter of 2017 and increased to 55.4\% in the same quarter of 2018 (National Bureau of Statistics, 2018). Although an earlier report has shown that more than $70 \%$ of young individuals were living in abject poverty; that is to say that these set of young individuals were living below the poverty line, while one-third were said to be surviving on less than 1 dollar a day (NBS, 2012).

Research have also shown that there is an increased rate of insecurity and students' dropout. For instance, Edokpolor and Owenvbuigie (2017) stated that young individuals (including business education graduates) who are unemployed and poor have probably become suicide bombers, fear-based oppressors, criminals, aggressors, vandals, outfitted looters, and many more, thereby adding to a significant loss in revenue earnings which has affected Nigerian economic development. Also, Edokpolor (2018) stipulated that business education students often exhibit low self-confidence and determination towards lifelong learning. Edokpolor and Dumbiri (2019) averred that the reason for the increasing rates of students' dropout could be linked to the low supply of human, financial and material resources, which seem to have hindered the acquisition of 21st century skills required to be capable of taking part in entrepreneurial and lifelong learning activities immediately after graduation. These situations have become a treat to apparently all stakeholders in the country.

The increasing rates of unemployment and all manner of social ills in the country suggest that young individuals (including business education graduates) were not given the opportunity to learn experientially, which appear to hinder the process of acquiring employability skills needed to be capable of participating in entrepreneurial and lifelong learning activities right after graduation. The low-level or premature skills acquired by the business education graduates during studies could be attributed to the theoretical nature of the business education curriculum in Nigeria. The existence of 'graduate skills gap' is because the business education graduates are prepared for the $21^{\text {st }}$ century workplaces using a theoretical-based curriculum that suite $20^{\text {th }}$ century. This implies that business education students are trained to be employees who would act as good followers to few 'owners of businesses', yet it is expected that more and more students would start their own businesses instead of working for others. Business education students are also expected to continuously, quickly, and effectively learn new skills to function effectively as entrepreneurs.

If the goals of business education are to prepare students to become enterprising individuals and lifelong learners, the different skills set (such as, critical thinking, innovation, problem-solving, creativity, flexibility, adaptability, learning to learn, to list but a few) and the apprenticeship models (such as, technology-based learning, team-based learning, inquiry-based learning, problem-based learning, and project-based learning) need to be integrated into the business education curriculum. This assumption has earlier sparked strong discussions among academics and business practitioners whether entrepreneurship or small business skills can be learned (Aronsson \& Birch, 2004; Fayolle \& Gailly, 2013). Some evidence have been found to support the assumption that entrepreneurship or small business skills can only be learnt via an experientially oriented curriculum (Aronsson \& Birch, 2004; Fayolle, 2013; Sirelkhatim \& Gangi, 2015) that inculcates thoughts' and find solutions to problems (Global e-Schools and Communities Initiative, 2013). Indeed, educators and business practitioners have argued that one can actually learn entrepreneurship or small business skills (such as, selling, resource management, and product development) through some forms of apprenticeship models (Aronsson \& 
Birch, 2004). At this present time, it can be suggested that the question about, or of whether the skills to start and run a business can be learnt or not should move from its present discussion stage and focus on the questions emanating from the increasing rates of unemployment and all manner of social problems around the world: Does the current state of business education curriculum experiential in nature? Does the business education curriculum need a reformulation in order to equip recipients with the skills to engage in entrepreneurial and lifelong learning activities?

A skill is described as the ability to perform tasks and solve problems (OECD, 2009). The 21st century skills has been referred to sets of core subject skills, life and career skills, learning and innovation skills, and information and media technology skills (Partnership for 21st Century Skills, 2008). They can also be classified as cognitive, non-cognitive, and technical skills (Burton, 2013). The term 'apprenticeship', on the other hand, involves active or situated learning, which is one way of implementing experienced-based learning approaches (Canadians for 21st Century Learning and Innovation, 2012; Herring, 2012; Schleicher, 2012; UNESCO Bangkok, 2011; UNESCO Bangkok, 2012). A theoretical-based curriculum was built on the behaviourist learning theory postulated by Ivan Pavlov in which lecturers are sole source of student's learning (Molande, Mtemang'ombe \& Chikasanda, 2017). Yet, many education programmes (including business education) prefer to use this kind of curriculum to foster students' learning (Kennedy, Lawton \& Walker, 2001; Adeyemi, Boikhutso \& Moffat, 2003), despite its criticism of not capable of equipping students with higher order skills to start and be successful in their own entrepreneurial ventures (Munoz \& Huser, 2008).

From preceding paragraphs, one could infer that business education students are often not motivated to learn entrepreneurial or small business courses and have great difficulty in acquiring meaningful knowledge in the programme because a theoretical-based curriculum still seems to be used as the most common instructional approach. Ekpenyong (1999) have long pointed out that the business education lecturers usually place more premiums on impacting abstract knowledge using expository methods while experiential-based learning is relegated to the background. Freire (2000) faulted the theoretical-based educational curriculum which exposes students to Pavlov's thinking, that they can be conditioned so as to show some expected behaviour, which considers lecturers' as omnipotent and called for the use of an experiential-based curriculum that provides the opportunity for students to become 21st century critical thinkers in order to be empowered to question existing knowledge. Obunadike (2015) argued that an experiential-based curriculum (including that of business education) which are supposed to expose students to work-based learning environments that will help to bridge the gap between business education and the workplace has become a myriad. This is an uninteresting trend, even when experiential learning approach has long been considered as a major component of a business education curriculum with an explicit recognition that business education curriculum 'needs to reflect a real-world environment' (Bygrave, 1994; Feldman, 2001).

To overcome the ugly situation, there is a need for a reformulation of the business education curriculum. The major concern of this study is on how to reform the business education curriculum that would help respond to the skills needed by undergraduates to be capable of engaging in gainful and decent employment as well as lifelong learning activities immediately after graduation. Based on this situation, the study sought to provide answers to the following questions. First, what is the current implementation state of business education curriculum in Nigeria? Second, how does the reformulation of business education curriculum help equip undergraduates with 21st century skills to engage in entrepreneurial activities? Third, how does the reformulation of business education curriculum help equip undergraduates with the 21 st century skills to engage in lifelong learning activities? The study, therefore intends to: (1) assess the current implementation state of business education curriculum in Nigeria; (2) assess how the reformulation of business education curriculum can help equip undergraduates with the 21st century skills to engage in entrepreneurial tasks; and (3) assess how the reformulation of business education curriculum can help equip undergraduates with the 21st century skills to engage in lifelong learning activities immediately after graduation.

\section{RESEARCH METHOD}

This section describes the procedures that were used in conducting the study. These procedures were discussed under the following sub-headings: Research Design, Study Participants, Research Instrument, 
A reformulation of business education curriculum for the development of career opportunities among undergraduates of South Nigerian Universities

Instrument Validity and Reliability, and Data Collection and Analyses.

\section{Research Design}

A survey research design was used to achieve the specific objectives of the study. A survey design is a procedure in quantitative research in which a researcher administers a questionnaire to a small group of people (usually referred to as sample) to identify trends in attitudes, opinions, behaviours, or characteristics of a large group of people (usually referred to as population). This approach was employed to offer the authors the opportunity to have a personal interaction with the participants.

\section{Study Participants}

As shown in Table 1, the study participants comprised of 43 business education lecturers and 246 final year business education students from three Federal Universities in South-South geopolitical region of Nigeria, which include the University of Benin, University of Uyo, and University of Calabar. The South-South region consists of six States, namely: Edo, Delta, Uyo, Calabar, Bayelsa, and Porthearcort, and which were chosen for the study due to the location of the authors' institutions. However, Edo, Uyo and Calabar are the States that have Federal Universities currently offering business education programmes. The authors of the study did not attempt to apply any sampling procedure because the participants were manageable; that is, the participants were not too large to cover in the study.

Table 1. Demographic Data of Participants in South-South Nigerian Federal Universities

\begin{tabular}{|c|c|c|c|c|c|}
\hline S/N & Institutions & Lecturers & Students & Total & Percentage (\%) \\
\hline 1. & University of Benin & 13 & 97 & 110 & 38 \\
\hline 2. & University of Uyo & 14 & 67 & 81 & 28 \\
\hline 3. & University of Calabar & 16 & 82 & 98 & 34 \\
\hline & Total & 43 & 246 & 289 & 100 \\
\hline
\end{tabular}

\section{Research Instrument}

The authors of the study designed two instruments, one set to be administered to business education lecturers and the other to be administered to final year business education students, titled "Business Education Curriculum Reform and Career Opportunities among Undergraduates (BECRCOAU)". The instrument was a four-point scale, ranging from 4=Strongly Agree; 3=Agree; 2=Disagree, and 1=Strongly Disagree. The instrument consist of two sections, namely section A and B. Section A asked the participants to respond to their programme option and response category, while section B asked the participants to respond to the items generated from existing literature. The instrument consists of 46 items, where 16 items measure the current implementation state of the business education curriculum in Nigeria, 15 items measure how the reformulation of business education curriculum can help equip undergraduates with the $21^{\text {st }}$ century skills to engage in entrepreneurial activities, and 15 items measure how the reformulation of business education curriculum can help equip undergraduates with the $21^{\text {st }}$ century skills to engage in lifelong learning activities.

\section{Instrument Validity and Reliability}

A panel of 4 lecturers, 2 in business education and 2 in measurement and evaluation disciplines established the content validity of the instruments. A reliability test was conducted to ascertain the 
internal consistency of the instruments (Cronbach, 1951). The coefficients alpha obtained provides the overall reliability of the instruments and confirmed that the instruments can be utilized with the confidence to measure the current implementation state of business education curriculum; how the reformulation of business education curriculum can help equip undergraduates with the $21^{\text {st }}$ century skills to engage in entrepreneurial activities; and how the reformulation of business education curriculum can help equip undergraduates with the $21^{\text {st }}$ century skills to engage in lifelong learning activities. The results from the analysis showed that the instruments was highly reliable, with the Cronbach alpha coefficient values of $\alpha=.874$ for lecturers and .887 for students.

\section{Data Collection and Analyses}

Data obtained from the respondents were analyzed via quantitative statistics, such as the Mean and standard deviations by utilizing the Statistical Package for Social Sciences (SPSS) version 23.0. Descriptive statistics of Mean were used to answer the research questions and standard deviations were used to ascertain the degree to which responses of the respondents' were clustered around or deviated from Mean. The rule of choice was dependent on any Mean calculated scores equivalent to, or more than 2.50 implies that the respondents agree to the questionnaire items, and any Mean determined scores less than 2.50 suggests that the respondents disagree with the questionnaire items raised. Standard deviations values between .00 and .96 suggest that respondents' scores were very close, meaning that their answers were clustered around the Mean (Creswell \& Poth, 2017, 2018).

\section{RESULTS AND DISCUSSION}

This segment presents and discusses the results of the investigation dependent on the three research questions raised to achieve the purpose of the investigation.

\section{Research Question 1:}

What is the current implementation state of business education curriculum in Nigeria?

Results of the information presented in Table 2 shows that 16 items had the Mean scores of lecturers and students that ranges from 1.63 to 2.07 and 1.53 to 2.00 respectively and the comparing standard deviations values ranges from .618 to .988 and .558 to .967 respectively. Comparatively, each item of the Mean scores and standard deviations values for lecturers are not differ from that of students. The Mean scores imply that lecturers and students strongly disagreed in that the business education curriculum in Nigeria is theoretical in nature and does not prepare students to become entrepreneurs and lifelong learners. Rather, the business education curriculum in Nigeria prepare students to work for entrepreneurs or 'captains of industries'. The comparing standard deviations values imply that the lecturers and students Mean scores on the current implementation state of business education curriculum in Nigeria are very close irrespective of their different response categories. This finding further imply that lecturers' and students' scores are not clustered around the Mean irrespective of their different sense of maturity on business education curriculum exposure at the university level.

Table 2. Mean and standard deviations of the current implementation state of business education curriculum in Nigeria by Lecturers and Students.

\begin{tabular}{|c|c|c|c|c|c|}
\hline & 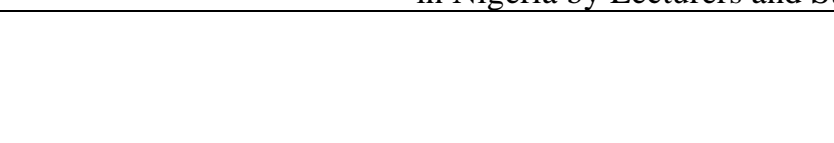 & Imp & $\begin{array}{l}\text { menta } \\
\text { iness } \\
\text { Curri }\end{array}$ & $\begin{array}{l}\text { on St } \\
\text { ducat } \\
\text { dlum }\end{array}$ & $\begin{array}{l}\text { ef } \\
\text { n }\end{array}$ \\
\hline & & $\begin{array}{c}\text { Lec } \\
(\mathbf{n}\end{array}$ & $\begin{array}{l}\text { rers } \\
\text { 85) }\end{array}$ & $\begin{array}{l}\text { Stu } \\
(\mathbf{n}=\end{array}$ & ents \\
\hline $\mathbf{S} / \mathbf{N}$ & Items & $M$ & SD & $M$ & SD \\
\hline 1. & $\begin{array}{l}\text { Business education curriculum prepare students to become } \\
\text { entrepreneurs. }\end{array}$ & 2.07 & .799 & 1.55 & .654 \\
\hline
\end{tabular}


A reformulation of business education curriculum for the development of career opportunities among undergraduates of South Nigerian Universities

\begin{tabular}{|c|l|c|c|c|c|}
\hline 2. & $\begin{array}{l}\text { Business education curriculum prepare students to become lifelong } \\
\text { learners. }\end{array}$ & 1.84 & .814 & 1.53 & .721 \\
\hline 3. & $\begin{array}{l}\text { Business education curriculum prepare students to work for } \\
\text { entrepreneurs. }\end{array}$ & 3.49 & .768 & 3.67 & .702 \\
\hline 4. & $\begin{array}{l}\text { Business education curriculum provide opportunity for students to } \\
\text { learn by being an apprentice. }\end{array}$ & 2.14 & .915 & 1.79 & .794 \\
\hline 5. & $\begin{array}{l}\text { Business education curriculum expose students to knowledge of } \\
\text { customer problems. }\end{array}$ & 1.88 & .793 & 1.78 & .565 \\
\hline 6. & $\begin{array}{l}\text { Business education curriculum expose students to knowledge of ways } \\
\text { to serve market. }\end{array}$ & 1.72 & .666 & 1.70 & .586 \\
\hline 7. & $\begin{array}{l}\text { Business education curriculum equip students with skill to sell tangible } \\
\text { products. }\end{array}$ & 1.63 & .618 & 1.59 & .598 \\
\hline 8. & $\begin{array}{l}\text { Business education curriculum equip students with skill to manage } \\
\text { resources. }\end{array}$ & 1.86 & .639 & 1.54 & .603 \\
\hline 9. & $\begin{array}{l}\text { Business education curriculum help students to generate new ideas to } \\
\text { improve on products. }\end{array}$ & 1.79 & .742 & 1.58 & .599 \\
\hline 10. & $\begin{array}{l}\text { Business education curriculum help students to conduct themselves in a } \\
\text { professional manner and relate with people from different cultures. }\end{array}$ & 1.88 & .762 & 1.62 & .620 \\
\hline 11. & $\begin{array}{l}\text { Business education curriculum equip students with skill to } \\
\text { communicate effectively with others in a business transaction. }\end{array}$ & 1.84 & .721 & 1.63 & .590 \\
\hline 12. & $\begin{array}{l}\text { Business education curriculum help students to reason critically and } \\
\text { solve problems. }\end{array}$ & 1.72 & .766 & 1.61 & .558 \\
\hline 13. & $\begin{array}{l}\text { Business education curriculum help students to access and evaluate } \\
\text { data effectively via ICT. }\end{array}$ & 1.79 & .675 & 1.61 & .595 \\
\hline 14. & $\begin{array}{l}\text { Business education curriculum equip students with skill to work with } \\
\text { divers' teams on an entrepreneurship-oriented project. }\end{array}$ & 1.65 & .720 & 1.63 & .596 \\
\hline 15. & $\begin{array}{l}\text { Business education curriculum help students to be determined and } \\
\text { optimistic toward starting a business. }\end{array}$ & 1.67 & .778 & 1.70 & .698 \\
\hline 16. & $\begin{array}{l}\text { Business education curriculum help students to work effectively in a } \\
\text { climate of constant changing condition and adapt to the situation at } \\
\text { hand. }\end{array}$ & 2.02 & .988 & 2.00 & .967 \\
\hline
\end{tabular}

$M=$ Mean, $\mathrm{SD}=$ Standard Deviations

\section{Research Question 2:}

How does the reformulation of business education curriculum equip undergraduates with $21^{\text {st }}$ century skills to engage in entrepreneurial activities?

Results of the information presented in Table 3 shows that 15 items had the Mean scores of teachers and students that ranged from 3.16 to 3.63 and 3.37 to 3.63 respectively and the comparing standard deviations values ranges from .506 to .955 and .565 to .980 respectively. Comparatively, each item of the Mean scores and standard deviations values for lecturers are not differ from that of students. The Mean scores further imply that lecturers and students strongly agreed in that the reformulation of business education curriculum can help equip undergraduates with $21^{\text {st }}$ century skills to engage in entrepreneurial activities. The comparing standard deviations values imply that the lecturers and students Mean scores on the reformulation of business education curriculum that can help equip undergraduates with $21^{\text {st }}$ century skills to engage in entrepreneurial activities are very close irrespective of their different response categories. This finding further imply that lecturers' and students' scores are not clustered around the Mean irrespective of their different sense of maturity on business education curriculum exposure especially at the university level.

Table 3. Mean and standard deviations of how the reformulation of business education curriculum equip undergraduates with 21st century skills to engage in entrepreneurial activities by Lecturers and Students.

Business Education
Curriculum Reform and
Lifelong Learning
Opportunities




\begin{tabular}{|c|c|c|c|c|c|}
\hline \multirow{2}{*}{$\mathbf{S} / \mathbf{N}$} & \multirow[b]{2}{*}{ Items } & \multicolumn{2}{|c|}{$\begin{array}{l}\text { Lecturers } \\
(\mathbf{n}=\mathbf{8 5})\end{array}$} & \multicolumn{2}{|c|}{$\begin{array}{l}\text { Students } \\
(\mathrm{n}=615)\end{array}$} \\
\hline & & $M$ & SD & $M$ & SD \\
\hline 1. & $\begin{array}{l}\text { Integrating team-based learning model into a business education } \\
\text { curriculum would provide entrepreneurial opportunities for students. }\end{array}$ & 3.40 & .849 & 3.37 & .980 \\
\hline 2. & $\begin{array}{l}\text { Integrating inquiry-based learning model into a business education } \\
\text { curriculum would provide entrepreneurial opportunities for students. }\end{array}$ & 3.44 & .734 & 3.51 & .681 \\
\hline 3. & $\begin{array}{l}\text { Integrating project-based learning model into a business education } \\
\text { curriculum would provide entrepreneurial opportunities for students. }\end{array}$ & 3.33 & .714 & 3.48 & .662 \\
\hline 4. & $\begin{array}{l}\text { Integrating problem-based learning model into a business education } \\
\text { curriculum would provide entrepreneurial opportunities for students. }\end{array}$ & 3.51 & .506 & 3.46 & .568 \\
\hline 5. & $\begin{array}{l}\text { Integrating technology-based learning model into a business education } \\
\text { curriculum would provide entrepreneurial opportunities for students. }\end{array}$ & 3.37 & .757 & 3.54 & .679 \\
\hline 6. & $\begin{array}{l}\text { Integrating selling skills into a business education curriculum would } \\
\text { provide entrepreneurial opportunities for students. }\end{array}$ & 3.35 & .870 & 3.44 & .647 \\
\hline 7. & $\begin{array}{l}\text { Integrating resource management skills into } \\
\text { curriculum would provide entrepreneurial op }\end{array}$ & 3.33 & .944 & 3.52 & .597 \\
\hline 8. & $\begin{array}{l}\text { Integrating creativity and innovation skills into a business education } \\
\text { curriculum would provide entrepreneurial opportunities for students. }\end{array}$ & 3.63 & .691 & 3.63 & .662 \\
\hline 9. & $\begin{array}{l}\text { Integrating communication skills into a business education curriculum } \\
\text { would provide entrepreneurial opportunities for students. }\end{array}$ & 3.44 & .765 & 3.59 & .618 \\
\hline 10. & $\begin{array}{l}\text { Integrating collaboration and teamwork skills into a business education } \\
\text { curriculum would provide entrepreneurial opportunities for students. }\end{array}$ & 3.16 & .871 & 3.51 & .570 \\
\hline 11. & $\begin{array}{l}\text { Integrating critical thinking and problem solving skills into a business } \\
\text { education curriculum would provide entrepreneurial opportunities for } \\
\text { students. }\end{array}$ & 3.21 & .914 & 3.39 & .608 \\
\hline 12. & $\begin{array}{l}\text { Integrating ICT literacy and numeracy skills into a business education } \\
\text { curriculum would provide entrepreneurial opportunities for students. }\end{array}$ & 3.44 & .765 & 3.45 & .602 \\
\hline 13. & $\begin{array}{l}\text { Integrating desirability and feasibility skills into a business education } \\
\text { curriculum would provide entrepreneurial opportunities for students. }\end{array}$ & 3.39 & .955 & 3.47 & .597 \\
\hline 14. & $\begin{array}{l}\text { Integrating flexibility and adaptability skills into a business education } \\
\text { curriculum would provide entrepreneurial opportunities for students. }\end{array}$ & 3.40 & .929 & 3.48 & .624 \\
\hline 15. & $\begin{array}{l}\text { Integrating learning to learn and self-direction skills into a business } \\
\text { education curriculum would provide entrepreneurial opportunities for } \\
\text { students. }\end{array}$ & 3.40 & .877 & 3.57 & .565 \\
\hline
\end{tabular}

$M=$ Mean, $\mathrm{SD}=$ Standard Deviations

\section{Research Question 3:}

How does the reformulation of business education curriculum equip undergraduates with $21^{\text {st }}$ century skills to engage in lifelong learning activities?

Results of the information presented in Table 4 shows that 15 items had the Mean scores of teachers and students that ranged from 3.16 to 3.53 and 3.48 to 3.72 respectively and the comparing standard deviations values ranges from .631 to .989 and .450 to .517 respectively. Comparatively, each item of the Mean scores and standard deviations values for lecturers are not differ from that of students. The Mean scores further imply that lecturers and students strongly agreed in that the reformulation of business education curriculum can help equip undergraduates with $21^{\text {st }}$ century skills to engage in lifelong learning activities. The comparing standard deviations values imply that the lecturers and students Mean scores on the reformulation of business education curriculum that can help equip undergraduates with $21^{\text {st }}$ century skills to engage in lifelong learning activities are very close irrespective of their different response categories. This finding further imply that lecturers' and students' scores are not clustered around the Mean irrespective of their different sense of maturity on business education curriculum exposure especially at the university level. 
A reformulation of business education curriculum for the development of career opportunities among undergraduates of South Nigerian Universities

Table 4. Mean and standard deviations of how the reformulation of business education curriculum equip undergraduates with $21^{\text {st }}$ century skills to engage in lifelong learning activities by Lecturers and Students.

\begin{tabular}{|c|c|c|c|c|c|}
\hline & \multicolumn{4}{|c|}{$\begin{array}{l}\text { Business Education } \\
\text { Curriculum Reform } \\
\text { and Lifelong Learning } \\
\text { Opportunities }\end{array}$} \\
\hline & & \multicolumn{2}{|c|}{$\begin{array}{l}\text { Lecturers } \\
(\mathbf{n}=\mathbf{8 5})\end{array}$} & \multicolumn{2}{|c|}{$\begin{array}{l}\text { Students } \\
(\mathrm{n}=615)\end{array}$} \\
\hline $\mathbf{S} / \mathbf{N}$ & Items & $M$ & SD & $M$ & SD \\
\hline 1. & $\begin{array}{l}\text { Integrating team-based learning model into a business education } \\
\text { curriculum would provide lifelong learning opportunities for students. }\end{array}$ & 3.53 & .827 & 3.71 & .480 \\
\hline 2. & $\begin{array}{l}\text { Integrating inquiry-based learning model into a business education } \\
\text { curriculum would provide lifelong learning opportunities for students. }\end{array}$ & 3.26 & .848 & 3.72 & .450 \\
\hline 3. & $\begin{array}{l}\text { Integrating project-based learning model into a business education } \\
\text { curriculum would provide lifelong learning opportunities for students. }\end{array}$ & 3.42 & .879 & 3.65 & .479 \\
\hline 4. & $\begin{array}{l}\text { Integrating problem-based learning model into a business education } \\
\text { curriculum would provide lifelong learning opportunities for students. }\end{array}$ & 3.47 & .702 & 3.67 & .481 \\
\hline 5. & $\begin{array}{l}\text { Integrating technology-based learning model into a business education } \\
\text { curriculum would provide lifelong learning opportunities for students. }\end{array}$ & 3.40 & .877 & 3.58 & .494 \\
\hline 6. & $\begin{array}{l}\text { Integrating selling skills into a business education curriculum would } \\
\text { provide lifelong learning opportunities for students. }\end{array}$ & 3.16 & .843 & 3.51 & .501 \\
\hline 7. & $\begin{array}{l}\text { Integrating resource management skills into a business education } \\
\text { curriculum would provide lifelong learning opportunities for students. }\end{array}$ & 3.37 & .725 & 3.48 & .517 \\
\hline 8. & $\begin{array}{l}\text { Integrating creativity and innovation skills into a business education } \\
\text { curriculum would provide lifelong learning opportunities for students. }\end{array}$ & 3.21 & .965 & 3.57 & .512 \\
\hline 9. & $\begin{array}{l}\text { Integrating communication skills into a business education curriculum } \\
\text { would provide lifelong learning opportunities for students. }\end{array}$ & 3.42 & .698 & 3.62 & .487 \\
\hline 10. & $\begin{array}{l}\text { Integrating collaboration and teamwork skills into a business education } \\
\text { curriculum would provide lifelong learning opportunities for students. }\end{array}$ & 3.33 & .993 & 3.61 & .489 \\
\hline 11. & $\begin{array}{l}\text { Integrating critical thinking and problem solving skills into a business } \\
\text { education curriculum would provide lifelong learning opportunities for } \\
\text { students. }\end{array}$ & 3.47 & .735 & 3.66 & .475 \\
\hline 12. & $\begin{array}{l}\text { Integrating ICT literacy and numeracy skills into a business education } \\
\text { curriculum would provide lifelong learning opportunities for students. }\end{array}$ & 3.35 & .870 & 3.65 & .477 \\
\hline 13. & $\begin{array}{l}\text { Integrating desirability and feasibility skills into a business education } \\
\text { curriculum would provide lifelong learning opportunities for students. }\end{array}$ & 3.30 & .989 & 3.63 & .484 \\
\hline 14. & $\begin{array}{l}\text { Integrating flexibility and adaptability skills into a business education } \\
\text { curriculum would provide lifelong learning opportunities for students. }\end{array}$ & 3.40 & .728 & 3.52 & .501 \\
\hline 15. & $\begin{array}{l}\text { Integrating learning to learn and self-direction skills into a business } \\
\text { education curriculum would provide lifelong learning opportunities for } \\
\text { students. }\end{array}$ & 3.47 & .631 & 3.62 & .486 \\
\hline
\end{tabular}

$M=$ Mean, $\mathrm{SD}=$ Standard Deviations

\section{DISCUSSION}

The aim of the study, in the first place, was to assess the current implementation state of business education curriculum in Nigeria. In the second place, the aim of the study was to assess how the reformulation of business education curriculum can help equip undergraduates with 21 st century skills to engage in entrepreneurial activities. In the third place, the aim of the study was to assess how the reformulation of business education curriculum can help equip undergraduates with 21 st century skills to engage in lifelong learning activities. The first and most important findings in this study is that 
business education curriculum in Nigeria is theoretically driven in nature and does not have the capacity of preparing the students to start their own business and continuously learn new skills. Rather, business education curriculum in Nigeria prepare students to work for entrepreneurs.

The findings from research question 1 is important for educators and business practitioners. The findings that business education curriculum is theoretical in nature and do not prepare students for entrepreneurship, have earlier attracted special debates and discussions. For instance, a business practitioner, David Birch, in an interview points out that business education curriculum around the world fall short in the increased use of practical learning especially through lengthy and meaningful apprenticeships (Birch \& Aronsson, 2004). Birch argued that business education prepare students to work for entrepreneurs and stress that few graduates end up being an entrepreneur; and that most graduates end up working for entrepreneurs. Birch noted that being a good servant is what business education teaches their students (Birch \& Aronsson, 2004). No doubt, business education students can be trained to work in entrepreneurial firms and even develop their skill set to take a managerial role in entrepreneurial ventures, but that doesn't make them owners of an entrepreneurial company.

Some scholars in entrepreneurship disciplines have also supported the notion that business education curriculum does not have the capacity of preparing students to start and grow their own business. Rather business education programme prepare students for corporate domain (Timmons, 1994), promotes a "take-a-job" mentality (Kourilsky, 1995), and suppress creativity and innovation (Chamard, 1989; Plaschka \& Welsch, 1990). Contrary to the views of these scholars, Katz (2003) opined that business education courses have enjoyed considerable worldwide growth. As a result, Cumming and Zhan (2018) reiterated that the debates and answers on whether the skills set needed to start and grow a business can be learnt seems clear, considering the growth of business education around the world. Nevertheless, the most challenging questions that ought to have attracted rigorous empirical inquiry in business or entrepreneurship education literature include: (1) does the current business education curriculum theoretical in nature? And (2) how does the reformulation of business education curriculum help to equip undergraduates with the skills needed to participate in entrepreneurial and lifelong learning activities? Jones and English (2004) argued that a learner-centred approach that is activity-oriented, supportive of experiential learning, problem-solving, project-based, creative, and involves peer evaluation need to be infused into the business education curriculum. They found in their study that students are more interested in entrepreneurial activities through this learning process. The experiential learning approach is the most common pedagogical approach applied in business education. Desplaces, Wergeles, and McGuigan (2009) further found in their study that experiential learning approach facilities students' entrepreneurial mind set, and provide students with real-life learning experiences that could help to strike a balance or bridge the gap between the skills set acquired and those skills set required to start and grow their own business.

The analysis of research question 2 reveals that the integration of $21^{\text {st }}$ century skills set into business education curriculum can provide opportunities for students to engage in entrepreneurial activities. This finding concurs with the study conducted by Wu and Martin (2018) who designed and employed an experiential curriculum course content to teach students on how to confidently engage in effective entrepreneurial activities in a developing country. Their experiential curriculum course content involves a short-term trip to Honduras, which is a semester-long entrepreneurship project, and structured students' reflections. Their study further demonstrated that an experiential curriculum course content can significantly influence students' attitudes and perceptions toward participating in social entrepreneurship activities. The authors also suggests that the arrangements of post-trip is critical to the development of students' entrepreneurial learning activities in a globalized world. These findings, therefore suggest that this course has the capacity of equipping students with the skills, and enhances and facilitates their learning in a business education course.

The finding from research question 2 also supported the assumption of career socialization theory which propose that the decision of individuals to pursue entrepreneurial careers is influenced by many social factors including exposure to educational experiences (Dyer, 1994). Shapero (1985) had earlier suggested that an individual's attitude or perception to engage in entrepreneurial career is directly influenced by his or her prior exposure to work experiences and existence of role models. These work experiences could influence an individual's decision or perception to pursue a career congruent with his or her work experiences (Peterman \& Kennedy, 2003; Shapero \& Sokol, 1982).

The analysis of research question 3 reveals that the integration of $21^{\text {st }}$ century skills set into 
business education curriculum can provide opportunities for students to engage in lifelong learning activities. This finding supports the assumption of experiential learning theory which proposes that learning is a socialization and continuous process by which knowledge or skills is created via the transformation of experience (Kolb, 1984). Experience-based theory is an integrative perspective that combines the constructs of learning and doing (Kolb, 1984). Experiential learning theory tells us that an experience-based curriculum would equip the students with the skills and abilities needed to confidently participate in their career (e.g., lifelong learning) goals and aspirations. Experiential learning theory provides opportunity to understand the importance of experience during learning, the relevance of perceiving learning as a continuous process, and the importance of conceptualizing learning as a continuing reconstruction of experience. Jung (1931) propounded the cyclical model of experiential learning, as an eternal process where the ending of the experience-based model (i.e., the experimentation of lifelong learning activity) become the beginning (i.e., the acquisition of new knowledge and skills) again and again. Thus, an experienced-based learning model often represents dual poles (i.e., the combination of learning and doing) that foster the endless process of learning.

From the preceding paragraphs, one would observe that an experientially acquired skills set through the business education curriculum could help to influence students' decisions to engage in lifelong learning activities. For instance, theorists (e.g., Barrows \& Tamblyn, 1980; Boud, 1985) viewed an experiential learning model, such as problem-based learning as an instructional approach that uses an authentic or a situated problem or challenge as a context for students to learn lifelong learning skills and acquire knowledge about a particular learning domain. The basic theory of this learning process is to encounter the problem first, with "... reasoning skills and identifying learning needs in an interactive process, self-study, applying newly gained knowledge to the problem, and summarizing what has been learned" (Barrows, 1985, p. 15). In a problem-based learning context, students work with problems in a manner that fosters reasoning and the application of appropriate knowledge to their levels of learning. In the process of collaboratively working on a problem and with their peers, students identify areas of learning to guide their own self-directed study. The skills and knowledge acquired through self-directed study are applied back to a problem to evaluate the effectiveness of learning and to reinforce learning. This process help students develop self-directed learning skills which is a critical component of lifelong learning (Dynan, Cate \& Rhee, 2008).

An experiential learning approach, such as team-based learning focuses on the development of lifelong learning skills via teamwork to promote thinking because collaborative activities engage students in an interactive approach to learning (Johnson \& Johnson, 1986). Collaborating with peers as resources plays an important role in team-based learning. First, team-based learning provide students with opportunities to see and hear how other students approach and acquire skills. Because the students in a collaborative group are working closely together, students are able to share ideas and perspectives, as well as help each other clarify issues. This is important in helping students develop $21^{\text {st }}$ century skills set. Accordingly, collaboration provides students with a support structure while they develop the $21^{\text {st }}$ century skills set needed to be lifelong learners. Therefore, within an experiential learning environment, collaboration is used to provide support for students as they develop the skills needed to be lifelong learners. Reliance on collaboration in reciprocal teaching is critical to the development of the metacognitive skills needed to learn from expository text the same metacognitive skills needed to engage in lifelong learning activities. This forces students to develop metacognitive awareness, a key component of the lifelong learning construct. Generally, students involved in apprenticeship activities (such as, technology-based learning, team-based learning, among others) impart the skills that will enable them to perform as lifelong learners. As such, there is good reason to believe that an experiential learning curriculum can help to foster or develop the interest in learning, which is necessary to create lifelong learners or contribute to an orientation toward lifelong learning (Sibthorp, Schumann, Gookin, Baynes, Paisley \& Rathunde, 2011).

\section{CONCLUSION AND RECOMMENDATIONS}

This study aimed at assessing the current implementation state of business education curriculum in Nigeria; how the reformulation of business education curriculum can help equip undergraduates with 
the $21^{\text {st }}$ century skills to engage in entrepreneurial activities; and how the reformulation of business education curriculum can help equip undergraduates with the 21 st century skills to engage in lifelong learning activities. The study reveals that the business education curriculum in Nigeria is theoretical in nature and does not prepare students to become entrepreneurs and lifelong learners. Rather, it prepares students' to work for entrepreneurs. The study also reveals that the reformulation of business education curriculum can help equip undergraduates with $21^{\text {st }}$ century skills to engage in entrepreneurial activities. The study further reveals that the reformulation of business education curriculum can help equip undergraduates with $21^{\text {st }}$ century skills to participate in lifelong learning activities. Based on these findings, the authors of this extant study concludes that the alarming rates of unemployment and all manner of social ills among the business education graduates, could be attributed to the theoretical nature of the business education curriculum. The authors also concludes that for business education graduates to start and be successful in running a business, there is need to integrate the different skills set and apprenticeship models into business education curriculum.

Based on the findings and conclusions, the study recommends that: First, managers of business education should endeavour to provide qualified lecturers and other relevant resources. This would help to ensure the implementation and reformulation of business education curriculum. Second, managers of business education should endeavour to collaborate with major stakeholders to be able to integrate the $21^{\text {st }}$ century skills and different models of apprenticeship into business education curriculum. This would help to equip undergraduates with the skills needed to pursue entrepreneurial activities immediately after graduation. Finally, managers of business education should endeavour to collaborate with major stakeholders to be able to integrate the $21^{\text {st }}$ century skills and different models of apprenticeship into business education curriculum. This would help to equip undergraduates with the skills needed to engage in lifelong learning activities immediately after graduation.

\section{REFERENCES}

Adeyemi, M. B., Boikhutso, K., \& Moffat, P. (2003). Teaching and learning of citizenship education at junior secondary level in Botswana. Journal of Pastoral Care Education, 21 (2), 35-40.

Aronsson, M., \& Birch, D. (2004). Education matters - but does entrepreneurship education? An interview with David Birch. Academy of Management Learning and Education, 3 (3), 289-292. http://dx.doi.org/10.5465/AMLE.2004.14242224

Barrows, H. S. (1985). How to design a problem-based curriculum for the preclinical years. NY: Springer Publishing Company.

Barrows, H. S., \& Tamblyn, R. N. (1980). Problem-based learning. NY: Springer Publishing Company.

Boud, D. (1985). Problem-based learning in education for the professions. Sydney, Australia: Higher Education Research and Development Society of Australia.

Bygrave, W. D. (1994). Portable MBA in entrepreneurship. NY: John Wiley and Sons.

Canadians for 21 st Century Learning and Innovation (2012). Shifting minds: A $21^{\text {st }}$ century vision of public education for Canada. Retrieved from https://www.c21canada.org/wpcontent/uploads/2012/11/Shifting-Minds-Revised.pdf

Chamard, J. (1989). Public education: Its effect on entrepreneurial characteristics. Journal of Small Business and Entrepreneurship, 6 (2), 23-30.

Cronbach, L. J. (1951). Coefficient alpha and the internal structure of tests. Psychometrika, 16 (3), 297-334.

Creswell, J. W., \& Poth, C. N. (2017). Qualitative inquiry and research design: Choosing among five approaches ( $3^{\text {rd }}$ ed.). Newbury Park, CA: SAGE Publications.

Creswell, J. W., \& Poth, C. N. (2018). Qualitative inquiry and research design: Choosing among five approaches ( $4^{\text {th }}$ ed.). Thousand Oaks, CA: SAGE.

Cumming, D., \& Zhan, F. (2018). International entrepreneurship education. Journal of Teaching in International Business, 29 (3), 181-184. https://doi.org/10.1080/08975930.2018.1514817

Desplaces, D. E., Wergeles, F., \& McGuigan, P. (2009). Economic gardening through entrepreneurship education: A service-learning approach. Review of Industry and Higher Education, 23 (6), 473-484. https://doi.org/ $10.5367 / 000000009790156436$.

Dyer, W. G., Jr. (1994). Towards a theory of entrepreneurial careers. Entrepreneurship Theory and Practice, 19 (2), 7-21.

Dynan L., Cate, T., \& Rhee, K. (2008). The impact of learning structure on students' readiness for self-directed learning. The Journal of Education for Business, 84 (2), 96-100. 
A reformulation of business education curriculum for the development of career opportunities among undergraduates of South Nigerian Universities

Edokpolor, E. J. (2018). Influence of self-efficacy antecedents on career decision-making among business education students in federal universities in south southern, Nigeria. Ibadan Journal of Educational Studies, 15 (2), 95-106. 17.

Edokpolor, E. J., \& Chukwu, M. E. (2017). E-commerce competencies acquired by office technology and management education students for proficiency in modern business organizations. Bayero Journal of Education in Africa, 6 (1), 63-72.

Edokpolor, J. E., \& Dumbiri, D. N. (2019). Resource adequacy and utilization for teaching and learning effectiveness in vocational education programmes in south-south Nigerian universities. Journal of Vocational Education Studies, 2 (1), 1-12. Retrieved from http://journal2.uad.ac.id/index.php/joves/article/view/727/pdf

Edokpolor, J. E., \& Egbri, J. N. (2017). Business education in Nigeria for value re-orientation: A strategic approach for poverty alleviation and national development. Journal of Educational Research and Review, 5(3), 41-48. $\quad$ Retrieved from http://sciencewebpublishing.net/jerr/archive/2017/May/Abstract/Edokpolor\%20and\%20Egbri.htm

Edokpolor, J. E., \& Owenvbiugie, R. O. (2017b). Technical and vocational education and training skills: An antidote for job creation and sustainable development of Nigerian economy. Problems of Education in the 21st Century, 75 (6), 535-549. Retrieved from http://www.scientiasocialis.lt/pec/node/files/pdf/vol75/535-549.Edokpolor_Vol.75-6_PEC.pdf

Ekpenyong, L. E. (1999). A reformulation of the theory of experiential learning appropriate for instruction in formal business education. Journal of Vocational Education and Training. 51 (3), 467-468.

Fayolle, A. (2013). Personal views on the future of entrepreneurship education. Entrepreneurship and Regional Development, 25, 692-701. http://dx.doi.org/10.1080/08985626.2013.821318

Fayolle, A., \& Gailly, B. (2013). The impact of entrepreneurship education on entrepreneurial attitudes and intention: Hysteresis and persistence. Journal of Small Business Management, 51, 315-328.

Feldman, J. M. (2001). Towards the post-university: Centre of higher and creative spaces as economic development and social change agents. Economic and Industrial Democracy, 22 (1), 10-12.

Freire, P. (2000). Pedagogy of the oppressed ( $30^{\text {th }}$ Anniversary Ed.). New York: Continuum.

Global e-Schools and Communities Initiative (2013). Development of 21 st century skills for innovation and enterprise: Exploring the role of Informal learning environments in the development of skills and aptitudes for the digital creative media industries. Retrieved from http://gesci.org/fileadmin/user_upload/2_Youth_Skills_Enterprise_Files/AKE_research_21C Skills Full Report_-2012.pdf.

Herring, S. (2012). Transforming the workplace: Critical skills and learning methods for the successful 21 st century worker. Retrieved from http://bigthink.com/experts-corner/transforming-the-workplace-criticalskills-andlearning-methods-for-the-successful-21st-century-worker

Johnson, R. T., \& Johnson, D. W. (1986). Circles of learning: Cooperation in the classroom. Alexandria, VA: Association for Supervision and Curriculum Development.

Jones, C., \& English, J. (2004). A contemporary approach to entrepreneurship education. Review of Education + Training 46, 8-9, 416-423. doi: 10.1108/ 00400910410569533.

Jung, C. G. (1931). Forward and commentary. In R. Wilhelm (Ed.). The secret of the golden flower. NY: Harcourt Brace \& World.

Katz, J. (2003). The chronology and intellectual trajectory of American entrepreneurship education 1876-1999. Journal of Business Venturing, 18, 283- 300

Kennedy, E. J., Lawton, L., \& Walker, E. (2001). The case for using live cases: Shifting the paradigm in marketing education. Journal of Marketing Education, 23 (2), 145-151.

Kolb, D. A. (1984). Experiential learning: Experience as the source of learning and development. Englewood Cliffs, New Jersey: Prentice-Hall.

Kourilsky, M. L. (1995). Entrepreneurship education: Opportunity in search of curriculum. Business Education Forum, October.

Lalley, J. P., \& Gentile, J. R. (2009). Classroom assessment and grading to assure mastery. Theory into Practice, $48(1), 28-35$.

Molande, E., Mtemang'ombe, D. M., \& Chikasanda, V. (2017). Effectiveness of problem-based learning for technical teacher training in woodwork at a Malawi college. International Journal of Vocational and Technical Education, 9 (5), 40-48.

Munoz, C., \& Huser, A. (2008). Experiential and cooperative learning: using a situation analysis project in principles of marketing. Journal of Education for Business, 83 (4), 214-220.

National Bureau of Statistics (NBS) (2012). The Nigeria poverty profile 2010 report. Retrieved from http://www.nigerdeltabudget.org/National\%20Bureau\%20of\%20Statistics\%20Poverty\%2Profile\%20of \%20Nigeria\%202012\%20(1).pdf 
National Bureau of Statistics (2018). Labor force statistics volume I: Unemployment and underemployment report. Retrieved from https://www.proshareng.com/admin/upload/reports/12246Q32018unemploymentbyState-proshare.pdf

Obunadike, J. C. (2015). Vocational and technical education: A tool for national development in Nigeria. In R. Okoye., J. E. O. Otuka \& S. Iheonunekwu (Eds.). Vocational and technical education in Nigeria: Trends and prospects. Onitsha: Global Academic Group Online Academic Resources.

OECD (2009). 21st Century Skills and Competences for New Millennium Learners in OECD Countries.

Partnership for 21st Century Skills (2008). 21st century skills, education and competitiveness. A resource and policy guide. Retrieved from http://www.p21.org/storage/documents/21st_century_skills_education_and_competitiveness_guide.pdf

Peterman, N., \& Kennedy, J. (2003). Enterprise education: Influencing Students' Perceptions of Entrepreneurship. Entrepreneurship Theory and Practice, 28 (2), 129-144.

Plaschka, P. R., \& Welsch, H. P. (1990). Emerging structures in entrepreneurship education: Curricular designs and strategies. Entrepreneurship Theory and Practice, 14 (3), 55-71.

Schleicher, A. (2012). Preparing teachers and developing school leaders for the 21st century: Lessons from around the world. OECD Publishing. Retrieved from http://www.oecd.org/site/eduistp2012/49850576.pdf

Shapero, A. (1975). The displaced, uncomfortable entrepreneur. Psychology Today, 133, 83-88.

Shapero, A., \& Sokol, L. (1982). Social dimensions of entrepreneurship. In C. Kent, D. Sexton, \& K. Vesper (Eds.). The encyclopedia of entrepreneurship. Englewood Cliffs, NY: Prentice Hall.

Sibthorp, J., Schumann, S., Gookin, J., Baynes, S., Karen Paisley., \& Rathunde, K. (2011). Experiential education and lifelong learning: Examining optimal engagement in college students. Journal of Experiential Education, 33 (4), 388-392.

Sirelkhatim, F., \& Gangi, Y. (2015). Entrepreneurship education: A systematic literature review of curricula contents and teaching methods. Cogent Business and Management, 2, 1-11. http://dx.doi.org/10.1080/23311975.2015.1052034

Timmons, J. A. (1994). New venture creation: Entrepreneurship for the $21^{\text {st }}$ century. Burr Ridge: Irwin.

Titiloye, K. A., \& Muhammed, A. A. (2016). Ethical issues in the usage of new technologies among students of business education in tertiary institutions. Nigerian Journal of Business Education, 3, 61-70.

UNESCO Bangkok (2011). Project implemented with Korea Funds-in-Trust (2010-2012) in Change

UNESCO Bangkok (2012). ICT-supported project-based learning: The myths and truths. Retrieved from http://www.unescobkk.org/education/apeid/news/news-details/article/ict-supported-projectbasedlearning-the-myths-and-truths/

Wu, Y., \& Martin, J. (2018). Incorporating a short-term abroad service trip for educating international entrepreneurship in the BOP market. Journal of Teaching in International Business, 29 (3). 